\title{
Effects of Thyroidectomy on Serum Levels of Growth Hormone, Insulin-Like Growth Factor (IGF)-1 and IGF-Binding Activity in Dwarf and Normal Chickens
}

\author{
Sadao Hoshino, Tomoko Nagai, Daisuke Morishita \\ and Masaaki WAKITA \\ Faculty of Bioresources, Mie University, Tsu-shi 514
}

\begin{abstract}
Surgical thyroidectomy tended to increase circulating concentrations of growth hormone $(\mathrm{GH})$ in normal Rhode Island Red chickens (Gifu 15 line) but not in dwarf ones (Gifu 20 line). The operation significantly reduced serum IGF-1 concentrations in normals but resulted in an increasing tendency in dwarfs. Serum IGF-binding activity decreased following thyroidectomy in dwarfs. Basal levels of IGF-binding activity were 3-times higher in dwarfs than in normals, presumably reflecting low basal concentrations of IGF-1 in dwarfs. The results suggest that circulating concentrations of IGF-1 as well as those of $\mathrm{GH}$ are influenced by thyroid status and dwarfing gene $d w$.

(Jpn. Poult. Sci., $30: 203-206,1993)$
\end{abstract}

Key words : thyroidectomy, dwarf, GH, IGF-1, IGF-binding activity

\section{Introduction}

The hormonal characteristics of the sex-linked dwarf chicken have been extensively investigated and it is well established that the dwarf chicken lacks GH receptor in the liver (BURNSIDE et al., 1991), which in turn results in an impaired IGF-1 production and a low circulating IGF-1 concentration (Hoshino et al., 1982 ; HuYBRECHTs et al., 1985). Further, a low triiodothyonine $\left(\mathrm{T}_{3}\right)$ concentration and/or rather a high thyroxine $\left(\mathrm{T}_{4}\right)$ concentration inherent to this strain (ScANES et al., 1983) are known to have a profound influence on GH secretion and IGF-1 status in the circulation. However, studies on serum IGF-binding proteins and their activities in dwarf chickens are scarce. These studies would serve the understanding of growth mechanisms, because of important roles of binding proteins for hormonal clearance and actions in the target tissues.

Recently we found that $\mathrm{T}_{4}$ supplement to propylthiouracil-induced hypothyroid cockerels provoked a marked increase in serum IGF-binding activity (MoRISHITA et al., 1991). In view of the hormonal situation of the dwarf chicken, it seems of interest to investigate serum IGF-binding activity in dwarf chickens and its responses to surgical thyroidectomy $(\mathrm{Tx})$ in comparison with normal chickens. 


\section{Materials and Methods}

One-day-old dwarf (Gifu 20 line) and normal (Gifu 15 line) Rhode Island Red male chicks were reared with free access to a commercial formula feed (21\% CP, 2,950 $\mathrm{ME} / \mathrm{kg}$ ) and water in a temperature controlled battery until 4 weeks of age and thereafter in an unheated brooder. At 4 weeks of age birds were weighed and surgically thyroidectomized under pentobarbital $(25 \mathrm{mg} / \mathrm{kg})$ anesthesia. The success of surgery was examined at autopsy by gross visual observation and only those birds successfully thyroidectomized were included in the results of experiments. The control group of birds underwent a sham operation. At 6 weeks of age, 14 days after operation, all birds were weighed and then killed to collect blood samples. The blood samples were centrifuged $(600 \times \mathrm{g}, 15 \mathrm{~min})$ after clotting at room temperature and the sera separated and stored at $-80^{\circ} \mathrm{C}$ to await analyses.

Concentrations of serum $\mathrm{T}_{4}, \mathrm{GH}$ and IGF- 1 were determined by radioimmunoassays as described before (WAKita et al., 1991 ; Morishita et al., 1991). Serum IGFbinding activity was determined as described by LEE et al. (1989). Serum total proteins and albumin were measured following the methods of LowRy et al. (1951) and Doumas et al. (1971). Statistical treatment of the results was done by a two-way analysis of variance and signfcance of differeuces betweeu means was assessed by Student's t-test.

\section{Results}

When compared to sham-operated groups, body weights in $\mathrm{Tx}$ groups were significantly decreased 2 weeks after the operation. Serum $\mathrm{T}_{4}$ concentrations were also decreased by $\mathrm{Tx}$ in both lines. Despite the presence of a small amount of $\mathrm{T}_{4}$ in $\mathrm{Tx}$ birds, the results may indicate the success of surgery, because of a possible presence of extrathyroidal tissue that produces thyroid hormones (HADDAD and MASHALY, 1989). The dwarf line had a slight, but not significant, lower body weight than the normal line at 6 weeks of age, though $30 \%$ reduction in mature dwarf chickens is known (Hoshino et al., 1992).

Serum GH concentrations in dwarfs tended to decrease following Tx, but those in normals showed a tendency to increase. The responses in serum IGF-1 concentrations to Tx also were reverse in the lines. Serum IGF-binding activity in dwarfs, but not in normals, showed a significant decrease following Tx. Concentrations of serum total proteins in normals were increased by $\mathrm{Tx}$, while there were no significant differences in albumin concentration between control and Tx birds of both lines.

Circulating basal concentrations of GH were significantly higher and those of IGF-1 lower in dwarf birds than in normal birds. Serum basal IGF-binding activity was extremely high in dwarfs. These diffrences in basal concentrations of GH and IGF-1 and IGF-binding activity between lines disappeared following Tx (Table 1).

\section{Discussion}

Circulating concentrations of $\mathrm{GH}$ showed a tendency to increase following $\mathrm{Tx}$ in 
Table 1. Effects of thyroidectomy (Tx) on body weights (BW), serum concentrations of thyroxine $\left(\mathrm{T}_{4}\right)$, growth hormone $(\mathrm{GH})$, insulin-like growth factor (IGF) -1 , total proteins and albumin, and on IGF-binding activity (IGF$\mathrm{BA}$ ) in dwarf and normal cockerels (Mean $\pm \mathrm{SE}, \mathrm{n}=5$ )

\begin{tabular}{|c|c|c|c|c|c|c|c|}
\hline & \multicolumn{2}{|c|}{ Dwarf } & \multicolumn{2}{|c|}{ Normal } & \multicolumn{3}{|c|}{$\begin{array}{l}\text { Analysis of } \\
\text { variance }\end{array}$} \\
\hline & Control & $\mathrm{Tx}$ & Control & $\mathrm{Tx}$ & Strain & $\mathrm{Tx}$ & $\begin{array}{l}\text { Inter- } \\
\text { action }\end{array}$ \\
\hline BW : Initial & $221 \pm 13$ & $224 \pm 8$ & $225 \pm 5$ & $213 \pm 7$ & NS & NS & $\mathrm{NS}$ \\
\hline $\begin{array}{r}\text { Final } \\
(\mathrm{g})\end{array}$ & $423 \pm 24$ & $318 \pm 15^{* *}$ & $461 \pm 10$ & $325 \pm 20^{* * *}$ & NS & $* *$ & NS \\
\hline $\mathrm{T}_{4}(\mathrm{ng} / \mathrm{m} l)$ & $11.73 \pm 0.67$ & $0.97 \pm 0.18^{* * *}$ & $9.62 \pm 0.74$ & $1.88 \pm 0.45^{* * *}$ & NS & $* *$ & $* *$ \\
\hline $\mathrm{GH}(\mathrm{ng} / \mathrm{m} l)$ & $174.8 \pm 11.7^{\dagger+\dagger}$ & $112.0 \pm 48.7$ & $70.7 \pm 12.3$ & 158. $7 \pm 76.1$ & NS & NS & NS \\
\hline$\stackrel{\operatorname{IGF}-1}{(\mathrm{ng} / \mathrm{m} l)}$ & $2.19 \pm 0.966^{\dagger \dagger \dagger}$ & $5.03 \pm 0.97$ & $20.51 \pm 2.59$ & $10.50 \pm 2.25^{*}$ & $* *$ & NS & $* *$ \\
\hline IGF-BA (\%) & $40.3 \pm 3.9^{\dagger \dagger}$ & $12.5 \pm 1.2^{* *}$ & $12.0 \pm 0.6$ & $12.1 \pm 0.8$ & $* *$ & $* *$ & $* *$ \\
\hline $\begin{array}{l}\text { Proteins } \\
\qquad(\mathrm{mg} / \mathrm{m} l)\end{array}$ & $40.1 \pm 1.9$ & $38.0 \pm 1.4$ & $36.0 \pm 1.1$ & $43.9 \pm 2.7^{*}$ & NS & NS & $* *$ \\
\hline$\underset{(\mathrm{mg} / \mathrm{m} l)}{\text { Albumin }}$ & $22.2 \pm 0.4$ & $22.4 \pm 1.0$ & $24.4 \pm 1.3$ & $22.9 \pm 1.9$ & NS & NS & NS \\
\hline
\end{tabular}

${ }^{*} \mathrm{P}<0.05,{ }^{* *} \mathrm{P}<0.01,{ }^{* * *} \mathrm{P}<0.001$ vs control (Student's t-test)

$+\mathrm{P}<0.05, \quad{ }^{\dagger} \mathrm{P}<0.01, \quad{ }^{+\dagger} \mathrm{P}<0.001$ vs normal (Student's t-test)

NS : not significant (ANOVA), ** P<0.01 (ANOVA)

normal birds, in accordance with the previous finding (HARvey et al., 1983). This seems highly likely to reflect thyroidal inhibition of circulating GH concentrations in the fowl, a peculiar effect not observed in mammals (HARvey et al., 1990). A possible increase in thyrotropin releasing hormone (TRH) following Tx may also be concerned with serum GH levels. However, this trend was not clear in dwarf birds, suggesting a different response in GH secretion to thyroid hormones. A higher basal level of GH in dwarfs may have modified the thyroidal effect on synthesis, release and clearance rates of $\mathrm{GH}$.

Responses in IGF-1 concentrations and binding activity in dwarfs following $\mathrm{Tx}$ also contrast to those in normals in a striking way. Apart from the well recognized low IGF-1 levels in dwarfs (Hoshino et al., 1982 ; HuyBrechts et al., 1985), it should be noted that the basal IGF-binding activity was 3-times higher in dwarfs than in normals, and $\mathrm{Tx}$ reduced it to normal levels without notable changes in serum concentrations of total proteins and albumin.Serum IGF-binding activity generally increases when circulating concentrations of IGF-1 are decreased by experimental treatments, such as fasting and hypophysectomy (MORISHita et al., 1993). Accordingly, the increased basal IGF-binding activity in dwarfs would be attributable to low circulating IGF-1 concentrations.

In the present study, changes in circulating concentrations of IGF-1 and GH following Tx suggest that IGF-1 concentrations are not entirely dependent on GH status. In addition, it is likely that IGF-1 levels as well as GH levels in the circulation are affected by thyroid state, the influence of which is modified by the 
presence of dwarfing gene $d w$.

\section{Acknowlegements}

We are grateful to NIDDK and NHPP, University of Maryland and School of Medicine for generous supply of IGF-1 antiserum (Somatomedin-C AS Underwood). The technical assistance of C. KAWAKAMI and R. YАMAмоTо is gratefully acknowleged.

\section{References}

Burnside, J., S.S. Liou and L.A. Cogburn (1991) Molecular cloning of the chicken growth hormone receptor complementary deoxyribonucleic acid: mutation of the gene in sex-linked dwarf chickens. Endocrinology, $128: 3183-3192$.

Doumas, B.T., W.A. Watson and H.G. Biggs (1971) Albumin standards and the measurement of serum albumin with bromcresol green. Clinica Chimica Acta, 31 : $87-96$.

HADDAD, E.E. and M.M. MAShaly (1989) Effect of thyroidectomy of immature male chickens on circulating thyroid hormones and on response to thyroid-stimulating hormone and chronic cold exposure. Poultry Science, 68: 169-176.

Harvey, S., R.J. Sterling and H. Klandorf (1983) Concentrations of triiodothyronine, growth hormone, and luteinizing hormone in the plasma of thyroidectomised fowl (Gallus domesticus). General and Comparative Endocrinology, 50 : 275-281.

Harvey, S., H. Klandorf and C.G. Scanes (1990) Participation of tri-iodothyronine and metabolic clearance rate in the inhibition of growth hormone secretion in thyroxinetreated domestic fowl. Journal of Endocrinology, $124: 215-223$.

Hoshino, S., M. Wakita, M. Suzuki and K. Yamamoto (1982) Changes in a somatomedinlike factor and immunoassayable growth hormone during growth of normal and dwarf pullets and cockerels. Poultry Science, 61 : 777-784.

Hoshino, S., I. Yамамото and M. Wakita (1992) Effect of dwarfing gene dw on erythrocyte counts, hematocrits and hemoglobin concentrations in chickens during 1 to 30 weeks of age. Japanese Poultry Science, $29:$ 151-155.

Huybrechts, L.M., D.B. King, T.J. Lauterio, J.A. Marsh and C.G. Scanes (1985) Plasma concentrations of somatomedin-C in hypophysectomized, dwarf and intact growing domestic fowl as determined by heterologous radioimmunoassay. Journal of Endocrinology, $104: 233-236$.

Lee, P.D., A. Peacock, M.K. Roessler, J. Hester and J.T. Reeves (1989) Insulin-like growth factor (IGF)-1 and IGF-binding activity in normal and fast-growing chickens. Life Science. $45: 2465-2470$.

Lowry, O.H., N.J. Rosebrough, A.L. FarR and R.J. Randall (1951) Protein measurement with the Folin phenol reagent. Journal of Biological Chemistry, 193 : 265-275.

Morishita, D., M. Wakita and S. Hoshino (1991) Effects of hypophysectomy, feeding of propylthiouracil and thyroxine supplement on IGF-1-binding activity of cockerel serum proteins. Proceedings of the Japan Society for Comparative Endocrinology, $6: 59$.

Morishita, D., M. Wakita and S. Hoshino (1993) Effect of hypophysectomy on insulinlike growth factor (IGF)-1 binding activity of serum in chickens. Comparative Biochemistry and Physiology, $104 \mathrm{~A}: 261-265$.

Scanes, C.G., J.A. Marsh, E. Decuypere and P. Rudas, (1983) abnormalities in the plasma concentrations of thyroxine, triiodothyonine and growth hormone in sexlinked dwarf and autosomal dwarf White Leghorn domestic fowl (Gallus domesticus). Journal of Endocrinology, $97:$ 127-135.

Wakita, M., C. Kawakami and S. Hoshino (1991) Purification of chicken growth hormone $(\mathrm{cGH})$ and development of a radioimmunoassay for cGH. Proceedings of the Japan Society for Comparative Endocrinology, $6: 33$. 